\title{
An Analysis of Pronouns Used in Selected International Journal Articles: Exploring Authors' Flexibility and Consistency
}

\author{
Rumintang Harianja ${ }^{1}$, Ratih Saltri Yudar ${ }^{2}$, Susy Deliani ${ }^{3}$, \\ Mutia Sari Nursafira ${ }^{4}$ and Budianto Hamuddin ${ }^{5}$ \\ 1, 2, ${ }^{4}$ Universitas Lancang Kuning, Pekanbaru, Indonesia \\ ${ }^{3}$ Universitas Muslim Nusantara Al-Wasliyah, Medan, Indonesia \\ ${ }^{5}$ Universitas Hasanuddin, Makassar, Indonesia \\ budihamuddin@pasca.unhas.ac.id
}

\begin{abstract}
ARTICLE HISTORY
Received : 2019-09-01

Revised : 2019-12-13

Accepted : 2019-12-27
\end{abstract}

\section{KEYWORDS}

International Journal

Pronouns

Analysis

Unique

Fame

\begin{abstract}
This study aims at identifying the pronouns used in journal articles in terms of numbers and familiarity. The data taken from three different journals from three various fields, i.e., Education, Medics and Engineering. It consists of 21 articles taken from the current issue 2018, where this study started. It is selected conveniently due to its unique and fame as a discipline and reputable sources. In collecting the data, the researcher accessed the journals published by science direct (Q1 Scopus indexed). The analysis showed that the writer in these three international journals commonly used several pronouns interchangeably. However, some articles in journal from Medical and Engineering consistently used only one chosen pronoun, which was recorded found at different sections in the journal article. The data then coded and transcribed to ease the analysis in this researcher. As a result of the study, it was found out that the data showed 19 kinds of pronouns in total were used in these three different fields. These results showed us that the pronoun usage in a scientific article from these three various fields varies with options of different pronouns. The pronoun seems used to help the impact of imposition and showing politeness or quality of the articles.
\end{abstract}

\section{Introduction}

Publications of research articles in international journals currently become an emerging issue in Indonesia. Under a new regulation from the General Directorate of Higher Education of Indonesia's Ministry of National Education, publishing in scientific journals is required as a prerequisite for undergraduate and doctoral qualification. Writing and getting acquainted with a scientific article is therefore essential for students today.

Moreover, sometimes when authors write articles, the authors include their style and prior knowledge that affect how someone or something (Pronoun) is mentioned in their article. The important thing for the correct use of pronouns in journal articles selected by the authors is that the readers can view the style and position of the authors. A pronoun is important in scientific articles in the sentence that develops or points an object directly into the sentence. Pronoun can refresh objects and subjects. In addition, the use of pronouns can improve our paper, as we can manage someone or something directly in study pronouns and can avoid something repeatedly. However, Wallwork, A. (2016). (2016). In his article, mentioned researchers from different disciplines write and sometimes follow a different structure in different ways. For example, there are significant differences in the form of the writing and construction of a medical, mathematical and sociological document.

Therefore, this study finds that a pronoun in this selected reputable journal can help to expand custom and style knowledge by using the correct pronoun that can be applied later. Also, how the researcher strategically utilizes pronoun knowledge to mention specific objects in their articles seems to have a different communicative purpose. Myers (1989) also mentions, in his phenomenon article " The pragmatics of politeness in scientific articles," the pronoun can represent the writers' intent to avoid misunderstandings, or display unity and respect for readers or peers in their article. In line with its review, each author has its own style, and each journal has its practice. (Hamuddin, 2012). In addition, understanding the method and structure as well as the style or tradition of a good paper increases the probability of a positive publication of the manuscript submitted. It means that the writers will know not only the topic but also the way the article is written means that the selection of a pronoun is essential for the quality of writing. 
Therefore, this paper interested to analyze the used of pronouns in selected scientific articles, especially. The pronoun will be observed regarding the use of the chosen pronoun from a prominent journal in 3 different areas, i.e., Education, Medics and Engineering. Focusing on the use of the pronoun in each article journal and explore the use of pronoun employ by the authors in their article of the journal in current issue in these different areas, i.e., Education, Medical and Engineering. Based on the introduction above, the research questions focus on revealing the types of pronoun most widely used in selected foreign journal articles and finding out the authors consistently using or swiftly using the same pronoun throughout their article?

\subsection{International Journal Articles}

The international journal is an article that is written by an expert and published throughout the year. This is evolved from time to time include such as letters, short communications, review articles, research articles, case reports, editorials, and many supplementary articles. Zeinali et al. (2018) "Journal studies are classified into four general categories, including original papers, review articles, technical notes/notes and letters to editors." this is the way to open access for exploration scientific research and collaborative efforts in the various sciences such as medical, education, engineering etc.although this is multidisciplinary. Meo, S. A. (2018). "Writing and publishing a scientific paper in academic journals is a highly competitive, timeconsuming stepwise process". It is such as examining competitive to develop knowledge in a particular field which publicized on IT that makes it easier for all humans to share knowledge development.

\subsection{Pronoun}

Pronoun is a word that used to refer to someone or something. The most common pronouns are the personal pronouns, which refer to the person or people speaking or writing (first person), the person or people being spoken to (second person), or other people or things (third person). Frank (1972) “classifies pronouns into seven types. They are personal, interrogative, relative, demonstrative, reflexive, indefinite, and expletive.".

\section{Method}

This quantitative study employs descriptive analysis to reveals a phenomenology of selected pronoun used in reputable articles. This will be used to analyze in using pronouns selected International Journal Articles. This Descriptive quantitative- method of investigation is accomplished into research design stages. The writer obtained the data by searching selected articles which is from international journal article on three (3) different areas i.e., education, medical and engineering, and presented in tabulation form. International journal of Education research (Q1),
Journal of International Medical Research (Q1) and International journal of engineering Studies were selected due to their fame, to represent the fields. The study then selected the latest seventh (7) publication in 2018, where this study started in the beginning. A total of 21 articles then selected conveniently to be analyzed in order to see the use of pronoun by the authors from these three different fields.

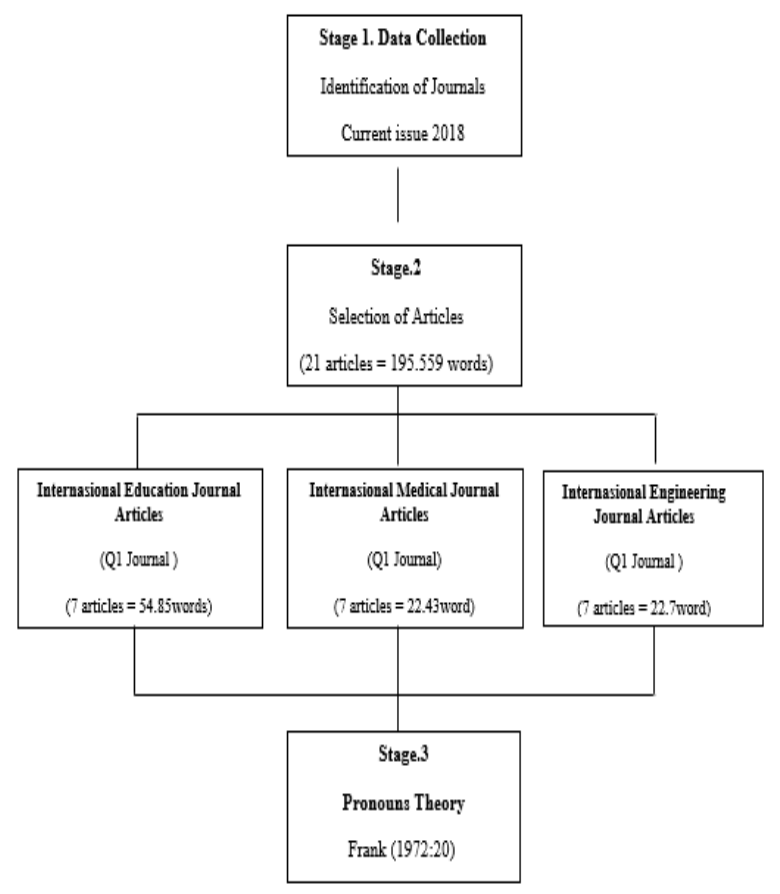

Figure 2.1 Conceptual framework

The corpus of the present study consists of 21 articles selected International Journal Articles in the current issue 2018 in three areas, i.e., Education, Medical, Engineering, as seen in the table below:

Table 2.1 The Selected Journals

\begin{tabular}{|c|c|c|c|c|c|}
\hline \multicolumn{2}{|c|}{ Education Journals } & \multicolumn{2}{|c|}{ Medical journals } & \multicolumn{2}{|c|}{ Engineering Journal } \\
\hline Articles & $\begin{array}{l}\text { Number } \\
\text { of words }\end{array}$ & Articles & $\begin{array}{l}\text { Number } \\
\text { of words }\end{array}$ & Articles & $\begin{array}{l}\text { Number } \\
\text { of } \\
\text { words }\end{array}$ \\
\hline IJER 1 & 9.340 & JIMR 1 & 2.605 & IJES 1 & 6.256 \\
\hline IJER 2 & 8.857 & JIMR 2 & 3.893 & IJES 2 & 4.398 \\
\hline IJER 3 & 9.254 & JIMR 3 & 3.396 & IJES 3 & 6.503 \\
\hline IJER 4 & 8.854 & JIMR 4 & 3.960 & IJES 4 & 9.278 \\
\hline IJER 5 & 6.493 & JIMR 5 & 3.176 & IJES 5 & 10.056 \\
\hline IJER 6 & 11.230 & JIMR 6 & 3.426 & IJES 6 & 7.252 \\
\hline IJER 7 & 10.452 & JIMR 7 & 6.391 & IJES 7 & 7.913 \\
\hline $\begin{array}{l}\text { Total of } \\
\text { articles: } \\
7\end{array}$ & $\begin{array}{l}\begin{array}{l}\text { Total of } \\
\text { the }\end{array} \\
\text { word: } \\
107.278 \\
(54.85 \%)\end{array}$ & $\begin{array}{l}\text { Total of } \\
\text { articles: } \\
7\end{array}$ & $\begin{array}{l}\text { Total of } \\
\text { words: } \\
43.877 \\
(22,43 \%)\end{array}$ & $\begin{array}{l}\text { Total of } \\
\text { articles: } \\
7\end{array}$ & $\begin{array}{l}\begin{array}{l}\text { Total } \\
\text { of }\end{array} \\
\text { words: } \\
44.404 \\
(22.7 \%)\end{array}$ \\
\hline Total & & & 195.559 & & \\
\hline
\end{tabular}


A total of words 195.559 is used corpus of this study of which Education 107.278 (54.85\%) of words. Medical 43.877 (22.43\%), Engineering 44.404 $(22.7 \%)$ words selected international journal articles. Furthermore, in the selection of the journal, this study selected from current issue 2018. Finally, a total of selected Articles journal is 21 from each of Education, Medical and Engineering form the corpus of this present study. To analyze data, this study sets its analysis on the total of using pronoun, and then the researcher makes the percentage from the total of data from each journal. Nevertheless, the researcher makes the diagram form to display the data revealed. Finally, the researcher will count the percent of data by using below formula and make the interpretation:

$\mathrm{P}=$ Frequency $\times 100 \%=\mathrm{N}$

Where:

$$
\begin{aligned}
& \mathrm{P}=\text { percentage } \\
& \mathrm{F}=\text { frequency } \\
& \mathrm{N}=\text { total number of data } \\
& 100=\text { constant multiple }
\end{aligned}
$$

\section{Findings}

\subsection{The Most Frequently Used Pronoun (Fame)}

The result of kinds of most frequently pronouns A total of seven articles published from International Journal of Educational Research (IJER) in current issue 2018 formed the corpus. Throughout this chapter, the following abbreviations used were:

Table 3.1 Pronoun in IJER

\begin{tabular}{clcc}
\hline $\mathbf{N}$ & \multicolumn{1}{c}{ Pronoun } & Frequency & $\begin{array}{c}\text { Percentage } \\
\mathbf{( \% )}\end{array}$ \\
\hline 1 & This study & 42 & 36.8 \\
2 & This research & 7 & 6.1 \\
3 & This article & 2 & 1.7 \\
4 & This paper & 15 & 13 \\
5 & This current study & 1 & 0.8 \\
6 & The paper & 2 & 1.7 \\
7 & The study & 12 & 10.5 \\
8 & The current study & 4 & 3.5 \\
9 & The research & 9 & 7.8 \\
10 & The article & 12 & 10.5 \\
11 & The present study & 1 & 0.8 \\
12 & The present research & 1 & 0.8 \\
13 & The case study & 5 & 4.3 \\
14 & The present article & 1 & 0.8 \\
\hline & $\quad$ Total & $\mathbf{1 1 4}$ & $\mathbf{1 0 0 \%}$ \\
\hline
\end{tabular}

As seen in Table 3.1, the study follows up a total of 114 in using pronoun were found in the IJER corpus. The pronouns of informing readers as followed by this research had $6.1 \%$ in total, this article, and the paper delivered the same total which was $1.7 \%$, this paper had $13 \%$, the study with $10.5 \%$, the current study was $3.5 \%$, the research was $7.8 \%$, the article was had $10.5 \%$, the present study, this current study, the present research and the present article come together in $0.8 \%$, the last one, the case study, was in 4.3 current study, the present research and the present article come together in $0.8 \%$, the last one the case study was in $4.3 \%$. It means in this education journal "this study" seems to show its fame comparing other pronouns.

Table 3.2 Pronoun in JIMR

\begin{tabular}{clcc}
\hline No & \multicolumn{1}{c}{ Pronoun } & Frequency & $\begin{array}{c}\text { Percentage } \\
(\boldsymbol{\%})\end{array}$ \\
\hline 1 & This study & 17 & 42.5 \\
2 & This case-control & 2 & 5 \\
3 & study & 6 & 15 \\
4 & This current study & 9 & 22.5 \\
5 & The study & 5 & 12.5 \\
6 & The current study & 1 & 2.5 \\
\hline & Total & $\mathbf{4 0}$ & $\mathbf{1 0 0 \%}$ \\
\hline
\end{tabular}

As seen in Table 3.2, the study follows up a total of 40 pronoun word were found in the JIMR corpus. The pronoun of informing readers about the research by using this study was $42.5 \%$, followed by this casecontrol study in 5 , this current study in $6 \%$, this study had $22.5 \%$, the present study was $12.5 \%$, and last, the current study was $2.5 \%$. It means in the medical journal "this study" seems to show its fame comparing other pronouns.

Table 3.3 Pronoun in IJES

\begin{tabular}{clcc}
\hline No & Pronoun & Frequency & $\begin{array}{c}\text { Percentage } \\
(\mathbf{\%})\end{array}$ \\
\hline 1 & This paper & 11 & 28.9 \\
2 & This study & 19 & 50 \\
3 & The present & 4 & 10.5 \\
4 & study & 1 & 2.6 \\
5 & We use & 1 & 2.6 \\
6 & We introduce & 1 & 2.6 \\
7 & We hive & 1 & 2.6 \\
\hline & Total & $\mathbf{3 8}$ & $\mathbf{1 0 0 \%}$ \\
\hline
\end{tabular}

As seen in Table 3.3, the study follows up a total of 38 in using pronoun were found in the IJES corpus. The pronoun of informing readers about the research by using this paper was $28.9 \%$, this study had $50 \%$ follows by the present study with $10.5 \%$ and we use, we give, we have seen it out with $(2.6 \%)$. This means in engineering journal "this paper" seems showing its fame comparing other pronouns.

\subsection{The Consistency of Pronouns Used}

This section presents the analysis consistently of data being in use pronouns of education journal as illustrated in table 3.4. The consistency means that the authors used a specific pronoun to represent his/their team in the article body text. While flexibility means that the author used more than one pronoun interchangeable in the text. Therefore, this study presents its data based on the author's consistency or flexibility in their writing. 
Table 3.4 Pronoun Consistency-Flexibility in IJER

\begin{tabular}{|c|c|c|c|}
\hline NO & $\begin{array}{l}\text { Education } \\
\text { Journals }\end{array}$ & $\begin{array}{l}\text { Statistic } \\
\text { Consistent/ } \\
\text { Flexible }\end{array}$ & Pronoun Use \\
\hline 1 & IJER 1 & Flexible & $\begin{array}{l}\text { This study, the } \\
\text { research, } \\
\text { research. }\end{array}$ \\
\hline 2 & IJER 2 & Flexible & $\begin{array}{l}\text { The article, this } \\
\text { article, this research, } \\
\text { this study. }\end{array}$ \\
\hline 3 & IJER 3 & Flexible & $\begin{array}{l}\text { This paper, the } \\
\text { paper, the study. }\end{array}$ \\
\hline 4 & IJER 4 & Flexible & $\begin{array}{l}\text { The case-study, this } \\
\text { paper. }\end{array}$ \\
\hline 5 & IJER 5 & Flexible & $\begin{array}{l}\text { This paper, this } \\
\text { present article. }\end{array}$ \\
\hline 6 & IJER 6 & Flexible & $\begin{array}{l}\text { This study, this } \\
\text { paper, this study, the } \\
\text { current-study, the } \\
\text { research. }\end{array}$ \\
\hline 7 & IJER 7 & Flexible & $\begin{array}{l}\text { This research, this } \\
\text { study, this current- } \\
\text { study, the study, the } \\
\text { research, the present } \\
\text { research, the present } \\
\text { study. }\end{array}$ \\
\hline
\end{tabular}

From the sample above, this might indicate the pronouns used by scientific writers in international journal education by seven journals are more flexible and not only use a single pronoun.

Table 3.5 Consistent/Flexible in JIMR

\begin{tabular}{|c|c|c|c|}
\hline NO & $\begin{array}{l}\text { Medical } \\
\text { Journals }\end{array}$ & $\begin{array}{l}\text { Statistic } \\
\text { Consistent/ } \\
\text { Flexible }\end{array}$ & Pronouns Use \\
\hline 1 & IJMR 1 & Flexible & This study, the study \\
\hline 2 & IJMR 2 & Flexible & $\begin{array}{l}\text { This study, the present- } \\
\text { study, the study, the } \\
\text { current study. }\end{array}$ \\
\hline 3 & IJMR 3 & Flexible & $\begin{array}{l}\text { This case control-study, } \\
\text { the study, this study, } \\
\text { this current-study, the } \\
\text { present study. }\end{array}$ \\
\hline 4 & IJMR 4 & Flexible & $\begin{array}{l}\text { The study, this study, } \\
\text { the study. }\end{array}$ \\
\hline 5 & IJMR 5 & Flexible & $\begin{array}{l}\text { This meta-analysis, this } \\
\text { study, the present- } \\
\text { study, the study. }\end{array}$ \\
\hline 6 & IJMR 6 & Flexible & $\begin{array}{l}\text { The study, this study, } \\
\text { the current-study. }\end{array}$ \\
\hline 7 & IJMR 7 & Consistent & The study \\
\hline
\end{tabular}

From the sample above, the pronouns used by scientific authors in an international medical journal by seven journals, show the journals in JIMR were 1- 6 journal is Flexible, and one journal is consistent in the use of pronouns.
Table 3.6 Consistent/Flexible in IJES

\begin{tabular}{llll}
\hline NO & $\begin{array}{l}\text { Engineering } \\
\text { Journals }\end{array}$ & $\begin{array}{l}\text { Statistic } \\
\text { Consistent/ } \\
\text { Flexible }\end{array}$ & Pronouns Use \\
\hline 1 & IJES 1 & Flexible & $\begin{array}{l}\text { This study, the present } \\
\text { study }\end{array}$ \\
2 & IJES 2 & Flexible & $\begin{array}{l}\text { This paper, this study, } \\
\text { the present study. }\end{array}$ \\
3 & IJES 3 & Consistent & $\begin{array}{l}\text { This present-study. } \\
4\end{array}$ \\
IJES 4 & Flexible & $\begin{array}{l}\text { We use, we introduce, } \\
\text { we give, the present } \\
\text { study, we have seen. }\end{array}$ \\
5 & IJES 5 & Consistent & This paper. \\
6 & IJES 6 & Flexible & This study, this paper. \\
7 & IJES 7 & Consistent & The study. \\
\hline
\end{tabular}

From the sample above, the pronouns in scientific writers on international engineering journals by seven journals show the journals on IJES on three journals are consistent and three journals more Flexible and one journal use subject pronouns in showing their journal articles.

\section{Discussion}

From the data analysis above, the researcher analysis of the corpus including twenty-one scientific articles from three scientific journals area (IJER, JIMR, and IJES) showed that experimental writers of the journals use journal pronouns in their texts. The researcher analyzed the kinds and differences in frequency of pronouns in three different fields. In this study, the researchers analyzed the number of pronouns that occurs in the entire area.

The researchers reveal nineteen kinds of pronouns; there are this study, this research, this article, this paper, this current study, the paper, the study, the current study, the research, the article, the present research, the present study, the case study, the present article, this case control-study, and besides that this study also found the subject pronouns that use by writer's style such as we introduce, we use, we give, we have seen. Wherefrom the data analysis found the most $o$ frequently use a pronoun in three fields was this study.

Based on the results in each different area in use pronouns to inform the reader how the writers called writers' articles. Where found out the data analysis in IJER on seven journals were Flexible. Next, the findings obtained from the results of data analysis that found in the JIMR field which found six journals that were flexible and one journal is consistent, furthermore, from analyst IJES data which finds four Flexible journals and three journals is consistent in using pronouns. The small difference between the use of pronouns in IJER, JIMR, and IJES showed that scientific writers use the pronoun preferred in their article. 
To display the preferred data this study conducted in IJER that found fourteen kinds pronoun in their articles and this study was the favourite one. Compared with JIMR in terms of frequency that use six kinds of pronouns and this study still the favourite one. The last IJES with use the favourite one was the study.

Based on the explanation above, the former had vast differences frequency in use the kinds of pronouns between IJER, JIMR and IJES Where from the data analysis found the most of frequently by use pronoun in three fields was this study. Showed the three scientific writers IJER, JIMR and, IJES used the different pronouns to illustrate their articles journals. Therefore, the result of text analysis based on the preference of scientific writers that use pronouns has different kinds of each other from three fields. It depends on each writer's style.

Nevertheless, this diverse to the results of the research conducted by Gray, B. (2010) who carried out about demonstrative research entitled "The Use of Demonstrative Practices and Determinations as to a Cohesive Device: Focus on these Initials in Academic Prose." The results of the study show that the use of pronouns "This and These" are the most widely used pronouns on antecedents and demonstrative use which is assumed by many nouns which are mostly abstract in academic writing.

Moreover, this comes out not so in line with Rustipa's (2015) who conducted the research entitled The Use of Pronoun Demonstrative and Demonstrative Determiner in Top-Level Student Writing: A Case Study. In their study, they found that the use of demonstrative determinants and demonstrative pronouns on top- levels were stable in supporting the relationship of text and context, the results of the study differed from this current study, which was more demonstrative as a reference in delivering an article. This might suggest that scientists such as Parfilova, and Karimova, (2016) conducted "the research entitle Adolescents' Demonstrative Behavior Research" pointing out that demonstrative usage is high in adolescents, this provides a statement that students among adolescents often face problems in interpersonal communication. This relates the equation indecisive use in this study which uses demonstrative elements as measuring the frequency of demonstrative usage in the delivery style to the reader.

Ataman, O., \& Çetinkaya, G. (2017). The Investigation of Preparatory Class Students' Subject of Pronouns and Possessive Adjectives. This research gives the results of the study in the use of subject pronouns which are more useful using the first person "I" in SP and "my" in PA. Ataman, O (2017), The Investigation of Preparatory Class Students' Subject of Pronouns and Possessive Adjectives. This research gives the results of the study in the use of subject pronouns which are more useful using the first person
"I" in SP and "my" in PA. The findings of this study state that the relationship in the use of subjects in showing the most frequently and types of kinds of pronouns, which in this current study only uses the subject pronouns "we" to use on one journal at IJES in the style of mentioning articles in international journals

\section{Conclusions}

The researchers reveals nineteen (19) different pronouns, i.e., this study, this research, this article, this paper, this current study, the paper, the study, the current study, the research, the article, the present research, the present study, the case study, the present article, this case control-study. Moreover, this study also found the subject pronouns that use by writer's style such as we introduce, and we use, we give, we have seen. The data analysis found the most frequently use (fame) pronoun in these three different fields was the use of this study. The authors from these three various fields, somehow showing flexibility or using pronoun interchangeability in their writing. Authors from Education fields showing more flexible than authors from the other two areas. Authors from medical and Engineering fields in the specific situation seems more consistent, or it might the author feel more convenience in using only a specific pronoun.

\section{Acknowledgement}

This research was partially supported by Pasca Sarjana UMN AL-Wasliyah Medan. We also thank our colleagues from Applied Linguistic Center PBIG FKIP Unilak who provided insight and expertise that greatly assisted the research, although they may not agree with all of the interpretations of this paper.

\section{References}

Ataman, O., \& Çetinkaya, G. (2017). The Investigation of Prefatory He Investigation of Preparatory Class Students'Use of Subject Pronouns and Possesive Adjective. Journal of Educational \& Instructional Studies in the World, 7(3).

Bell, J. (2014). Doing Your Research Project: A guide for first-time researchers. McGraw-Hill Education (UK).

Cho, D. W., \& Lee, K. (2016). English Relative Clauses in Science and Engineering Journal Papers: A comparative corpus-based study for pedagogical purposes. Ampersand, 3, 61-70.

Coventry, K. R., Griffiths, D., \& Hamilton, C. J. (2014). Spatial demonstratives and perceptual space: Describing and remembering object location. Cognitive Psychology, 69, 46-70.

Creswell, John W., 2005. Educational Research Planning, Conducting, and Evaluating Quantitative and Qualitative Research. New Jersey: Pearson Merrill Prentice Hall. 
Etelämäki, M. (2009). The Finnish Demonstrative Pronouns in Light of Interaction. Journal of Pragmatics, 41(1), 25-46.

Fergus, T. A., Griggs, J. O., \& Cunningham, S. C., \& Kelley, L. P. (2017). Health Anxiety and Medical Utilization: The Moderating Effect of Age Among Patients in Primary Care. Journal of anxiety disorders, 51, 79-85.

Frank in Putriani, R. (2015). Students' Abilities in Using Personal Pronoun in Their English Sentence (Doctoral dissertation, Semarang state university)

Gray, B. (2010). On The Use of Demonstrative Pronouns and Determiners as Cohesive Devices: A Focus on Sentence-initial this/these in Academic Prose. Journal of English for Academic Purposes, 9(3), 167-183.

Hamuddin, B. (2012). A Comparative Study of Politeness Strategies in Economic Journals (Doctoral dissertation, University of Malaya).

Hanson, W. E., Creswell, J. W., \& Clark, V. L. P., Petska, K. S., \& Creswell, J. D. (2005). Mixed Methods Research Designs in Counseling Psychology. Journal of counseling psychology, 52(2), 224.

Herlinawati, H. (2014). Feedback in English Writing for Indonesian EFL Students. ELT-Lectura, 1(1)

Holland, K. (2018). Ethical writing and publishing: Raising awareness for education and a shared responsibility for the future. Nurse education in practice, 32, A1.

Kamišalić, A., Riaño, D., Kert, S., Welzer, T., \& Zlatolas, L. N. (2019). Multi-level medical knowledge formalization to support medical practice for chronic diseases. Data \& Knowledge Engineering, 119, 36-57.

Laccourreye, O., Rubin, F., \& Maisonneuve, H. (2018). "Predatory" Journals Threatening the Scientific Medical Press. European annals of otorhinolaryngology, head and neck diseases, 135(1), 37-39.

Leal Filho, W., Raath, S., Lazzarini, B., Vargas, V. R., de Souza, L., Anholon, R., \& Orlovic, V. L. (2018). The Role of Transformation in Learning and Education for Sustainability. Journal of Cleaner Production, 199, 286-295.

Martin J.R and Rose D. 2003. Working with Discourse. Meaning beyond the Clause. London, New York : Continuum.McGraw-Hill Education (UK).

Meo, S. A. (2018). Anatomy and Physiology of a Scientific Paper. Saudi Journal of Biological Sciences, 25(7), 1278-1283.
Myers, G. (1989). The Pragmatics of Politeness in Scientific Articles. Applied linguistics, 10(1), 135 .

Okamura, A. (2009). Use of Personal Pronouns in Two Types of Monologic Academic Speech. The Economic Journal of Takasaki City University of Economics, 52(1), 17-26.

Parfilova, G. G., \& Karimova, L. S. (2016). Adolescents' Demonstrative Behavior Research. International Journal of Environmental and Science Education, 11(6), 1127-1135. Perceptual space: Describing and remembering object location. Cognitive Psychology, 69, 4670.

QC, J. T. (2012). The role of the Medical Expert in Care Proceedings. Paediatrics and Child Health, 22(5), 177-180.

Rustipa, K. (2015). The Use of Demonstrative Pronoun and Demonstrative Determiner" This" in UpperLevel Student Writing: A Case Study. English Language Teaching, 8(5), 158-167.

Safhira, S., \& Hamuddin, B. (2019). Online Interactive Communication via Academic Blogging Activities among Indonesian EFL Students. REiLA: Journal of Research and Innovation in Language, 1(2), 46-54. https://doi.org/10.31849/reila.v1i2.3131

Schulmeister, L. (2018). Publishing in Oncology Nursing: A Look to the Past, Present, and Future. In Seminars in oncology nursing (Vol. 34, No. 4, pp. 329-337). WB Saunders.

Trueger, N. S. (2018). Medical Journals in the Age of Ubiquitous Social Media. Journal of the American College of Radiology, 15(1), 173-176.

Udey, M. C. (2017). So this Is What Being the Editor of a Respected Scientific Journal Is like.... The journal of investigative dermatology, 137(10), 2037.

Zeinali-Rafsanjani, B., Mosleh-Shirazi, M. A., SaeediMoghadam, M., \& Sefidbakht, S. (2018). Evaluating the Distribution of Research in Radiation Sciences as Published in General Medical Physics Journals. The Egyptian Journal of Radiology and Nuclear Medicine, 49(4), 1119-1124. 